DOI: http://doi.org/10.30651/must.v5i1.3622

\title{
ANALISIS KEMAMPUAN PENALARAN SISWA DALAM MEMECAHKAN MASALAH MATEMATIKA BERDASARKAN LANGKAH-LANGKAH POLYA
}

\author{
Nathasa Pramudita Irianti \\ Universitas Tribhuwana Tunggadewi \\ nathasa1990@gmail.com
}

Received 21 November 2019; revised 2 July 2020; accepted 10 July 2020.

\begin{abstract}
ABSTRAK
Penelitian bertujuan untuk mendeskripsikan kemampuan penalaran siswa dalam memecahkan masalah matematika berdasarkan langkah-langkah Polya. Penelitian ini adalah penelitian deskriptif kualitatitf dengan subjek penelitian siswa kelas VIII MTs Muhammadiyah 1 Malang. Pemilihan subjek dilakukan dengan pemberian tes penalaran dan didapatkan dua subjek dengan penalaran tinggi, dua subjek dengan penalaran sedang, dan satu subjek dengan tingkat penalaran rendah. Selanjutnya, siswa diberikan tugas pemecahan masalah Sistem Persamaan Linear Dua Variabel dan wawancara berbasis tugas. Dalam pemecahan masalah, digunakan langkah-langkah pemecahan masalah menurut Polya, yaitu memahami masalah, menyusun rencana pemecahan masalah, melaksanakan rencana pemecahan, dan memeriksa kembali hasil pemecahan. Dari analisi data, siswa dengan kemampuan penalaran tinggi mampu memahami masalah, melakukan perencanaan pemecahan masalah, menyelesaikan pemecahan masalah secara tepat, serta dapat memeriksa kembali jawaban yang diperoleh. Siswa dengan kemampuan sedang juga mampu melakukan perencanaan pemecahan masalah serta mampu menyelesaikan pemecahan masalah secara tepat. Namun siswa tidak melakukan tahap pemeriksaan kembali. Siswa dengan kemampuan penalaran rendah tidak mampu dalam memahami masalah serta melakukan perencanaan pemecahan masalah. Penyelesaian masalah yang diberikan oleh siswa dengan kemampuan penalaran rendah juga tidak tepat dan tidak melakukan pemeriksaan kembali.
\end{abstract}

Kata kunci: langkah-langkah Polya, pemecahan masalah, penalaran siswa.

\section{ABSTRACT}

The research aims to describe students' reasoning abilities in solving mathematical problems based on Polya's steps. This research is descriptive qualitative research with the subject of VIII MTs Muhammadiyah 1 Malang students. Subject selection is done by giving a reasoning test and found two subjects with high reasoning, two subjects with moderate reasoning, and one 
subject with a low level of reasoning. Next, students are given the problem-solving task of the Linear Equation System of Two Variables and task-based interviews. In problem-solving, problem-solving steps are used according to Polya, namely understand the problem, devise a plan, carry out the plan, and look back. From the data analysis, students with high reasoning abilities are able to understand problems, devise a plan, carry out the plan, and look back. Students with moderate abilities are also able to do problem-solving planning and are able to solve problemsolving appropriately. But students do not do the look back step. Students with low reasoning ability are not able to understand problems and do problem-solving planning. The resolution of the problem that was given by student with low reasoning ability was also not right and did not do the look back step.

Keywords: Polya steps, problem solving, student's reasoning.

\section{PENDAHULUAN}

Mata pelajaran matematika diberikan kepada seluruh peserta didik mulai dari Sekolah Dasar hingga Pendidikan Tinggi untuk membekali mereka dengan kemampuan berpikir logis, analitis, sistematis, kritis, inovatif, dan kreatif, serta bekerjasama (Rosmaiyadi, 2017). Menurut National Council of Teachers of Mathematics, pembelajaran matematika di sekolah dari jenjang pendidikan dasar hingga kelas 12 berfungsi untuk membekali siswa dengan kemampuan berpikir kreatif, kemampuan penalaran matematis, pengetahuan serta keterampilan dasar yang bermanfaat (Mathematics, 2000). Sayangnya, masih banyak ditemui siswa yang mengalami kesulitan bahkan tidak sedikit siswa yang memiliki rasa ketakutan terhadap matematika. Salah satu penyebab dari ketakukan siswa ini adalah guru yang kurang dalam mengemas dan menyalurkan pengetahuan kepada siswa tentang matematika. Kamid berpendapat bahwa guru yang berkualitas adalah guru yang dapat memahami proses berpikir dan bernalar siswa tentang matematika dan bagaimana memperluas kemampuan bernalar mereka (Kamid, 2009). Sayangnya, kemampuan siswa dalam bernalar matematis ini masih kurang dipahami dan menjadi perhatian oleh guru.

Istilah penalaran matematis biasa dikenal juga dengan sebutan mathematical reasoning. Menurut Karin Brodie, penalaran matematis adalah penalaran mengenai dan dengan objek matematika (Brodie, 2010). Objek matematika yang dimaksud adalah cabang-cabang matematika seperti statistika, 
aljabar, geometri, dan sebagainya. Dalam pembelajaran matematika, kemampuan penalaran matematis diperlukan dalam pemahaman konsep hingga pada pemecahan masalahnya (Wulandari, 2011). Menurut Inayah, kemampuan penalaran sangat diperlukan dalam mencapai hasil belajar. Semakin tinggi tingkat penalaran yang dimiliki siswa, semakin mempercepat proses dalam mencapai tujuan pembelajaran (Inayah, 2016).

Kemampuan penalaran matematis siswa dapat dilihat ketika siswa menyelesaikan masalah matematika. Menurut Zaenab, untuk menyelesaikan masalah, salah satu yang diperlukan siswa adalah kemampuan dalam bernalar (Zaenab, 2015). Sayangnya, kemampuan siswa dalam menyelesaikan masalah matematika pun masih rendah (Irianti, Subanji, \& Chandra, 2016). Hal ini juga terjadi pada siswa kelas VIII MTs Muhammadiyah 1 Malang. Dari hasil wawancara dengan guru matematika di kelas VIII, diketahui bahwa dari 30 siswa, hanya 11 siswa yang memiliki nilai di atas KKM. Dalam pemecahan masalah matematika, Polya mengembangkan empat langkah pemecahan masalah, yaitu memahami masalah (understand the problem), menyusun rencana pemecahan masalah (make a plan), melaksanakan rencana pemecahan (carry out a plan), dan memeriksa kembali hasil pemecahan (look back at the completed solution) (Polya, 1973). Dalam penelitian ini, peneliti bermaksud untuk menganalisis kemampuan penalaran siswa dalam memecahkan masalah matematika berdasarkan langkahlangkah Polya.

\section{METODE PENELITIAN}

Penelitian ini bertujuan untuk mendeskripsikan kemampuan penalaran siswa dalam memecahkan masalah matematika berdasarkan langkah-langkah Polya. Berdasarkan tujuan tersebut, penelitian ini digolongkan sebagai penelitian kualitatif deskriptif. Proses yang diamati adalah kegiatan siswa pada saat menyelesaikan masalah matematika pada materi Sistem Persamaan Linear Dua Variabel.

Penelitian ini dilaksanakan di MTs Muhammadiyah 1 Malang. Subjek dalam penelitian ini adalah siswa kelas VIII semester 2 MTs Muhammadiyah 1 Malang. Pemilihan subjek penelitian ini didasari oleh pertimbangan bahwa siswa 
kelas VIII semester 2 telah memiliki pengalaman belajar yang cukup sehingga diharapkan dapat menyelesaikan soal-soal tentang pemecahan masalah terkhusus pada pokok bahasan Sistem Persamaan Linear Dua Variabel. Menentukan tingkat kemampuan penalaran siswa dilakukan dengan menggunakan instrumen bantu pertama yaitu tes penalaran. Tes kemampuan penalaran siswa terdiri dari 50 butir pertanyaan yang dapat menentukan tingkat penalaran siswa. Tingkat penalaran siswa dalam penelitian ini dikategorikan menjadi 3, yaitu penalaran tingkat tinggi, sedang, dan penalaran tingkat rendah.

Selanjutnya dari hasil pengelompokan tingkat penalaran siswa, dipilihkan siswa yang dapat mewakili tiap-tiap kategori penalaran. Pemilihan subjek ini mempertimbangkan kemampuannya dalam mengemukakan pendapat secara lisan. Subjek penelitian yang telah terpilih selanjutnya akan dianalisis kemampuan pemecahan masalahnya dalam menyelesaikan masalah matematika materi Sistem Persamaan Linear Dua Variabel.

\section{HASIL PENELITIAN DAN PEMBAHASAN}

Subjek penelitian ini adalah siswa kelas VIII MTs Muhammadiyah 1 Malang. Hasil analisis pengelompokan tingkat kemampuan penalaran siswa diperoleh 7 siswa dengan penalaran tinggi, 20 siswa dengan penalaran sedang, dan 3 siswa dengan penalaran rendah. Selanjutnya dari kelompok penalaran tinggi, penalaran sedang, dan penalaran rendah, dipilihlah 2 siswa dengan kemampuan penalaran tinggi, 2 siswa dengan kemampuan sedang, dan 1 siswa dengan kemampuan penalaran rendah yang akan dianalisis kemampuan pemecahan masalah matematikanya. Pemilihan ini berdasarkan saran dari guru dengan mempertimbangkan kemampuan siswa dalam mengemukakan pendapat dan jalan pikirannya secara lisan dan tulisan.

\section{Kemampuan penalaran subjek 1 dalam menyelesaikan masalah matematika}

Berdasarkan hasil pekerjaan siswa pada Gambar 1, terlihat bahwa siswa dapat memahami masalah. Hal ini dapat dilihat pada poin a dan $b$, dimana siswa mampu menuliskan apa yang diketahui pada soal (syarat cukup) dan apa yang ditanyakan pada soal sebagai syarat perlu. Terlebih lagi siswa juga mampu 
menentukan kecukupan syarat pada soal sehingga mampu menjawab pertanyaan yang diberikan.

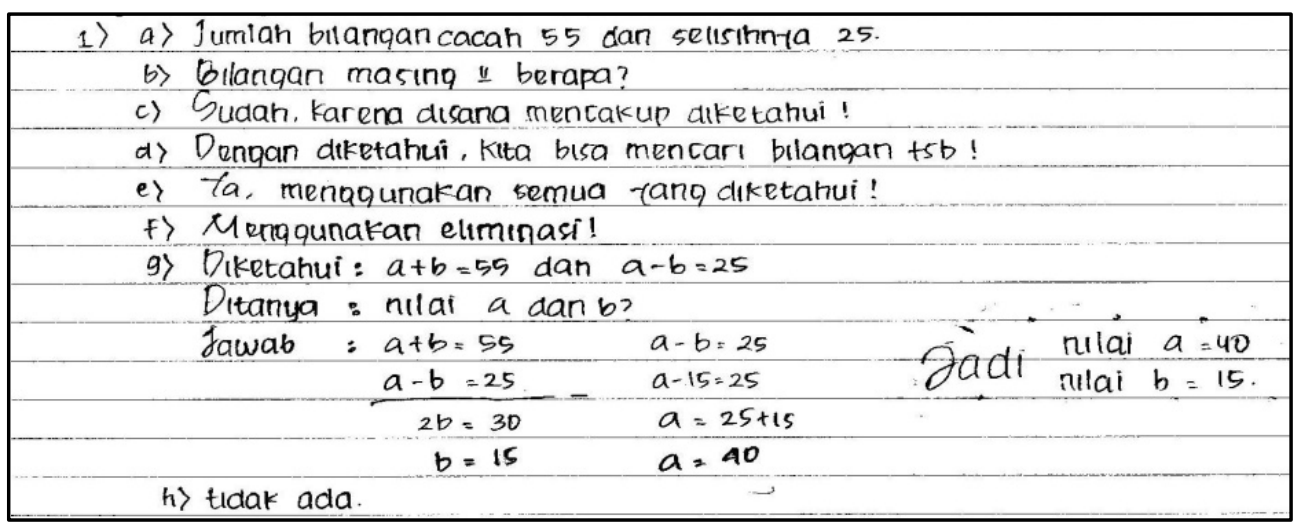

Gambar 1. Hasil Pekerjaan Subjek 1 dengan Kemampuan Penalaran Tinggi

Setelah memahami masalah, maka langkah selanjutnya adalah merencanakan penyelesaian masalah. Tahap perencanaan penyelesaian masalah, dapat terlihat pada poin $\mathrm{d}$, e, dan $\mathrm{f}$. Pada poin d siswa tidak menjelaskan secara jelas hubungan antara yang diketahui dengan yang ditanyakan pada soal. Siswa hanya menuliskan bahwa "dengan yang diketahui, kita bisa mencari bilangan tersebut". Langkah perencanaan selanjutnya adalah siswa menggunakan semua unsur yang diketahui pada soal untuk menjawab masalah yang ada.

Langkah selanjutnya adalah melaksanakan rencana penyelesaian masalah. Penyelesaian masalah yang dikerjakan oleh siswa menggunakan metode eliminasi. Terlihat bahwa siswa mengeliminasi dua buah persamaan $a+b=55$ dan $a-b=25$. Pada hasil pekerjaan, nampak bahwa siswa tidak menjelaskan terlebih dahulu maksud dari dua persamaan tersebut dan apa arti variabel $a$ dan $b$. Hasil eliminasi dua persamaan tersebut diperoleh nilai $a=40$ dan $b=15$.

Tahap yang terakhir adalah memeriksa kembali jawaban yang diperoleh. Pada tahap ini siswa tidak menuliskan bagaimana cara siswa memeriksa kembali jawaban yang telah diperoleh. Berdasarkan hasil wawancara terhadap siswa, nampak bahwa siswa mampu menjelaskan apa yang diketahui dan dinyatakan pada soal secara benar dan tepat.Selanjutnya dalam tahap penyelesaian masalah siswa mampu menjelaskan secara tepat mengenai arti variabel yang digunakan.Variabel tersebut yaitu $a$ yang menyatakan bilangan pertama dan $b$ yang menyatakan bilangan kedua. Siswa juga menjelaskan bahwa tidak harus 
variabel $a$ yang menyatakan bilangan pertama. Pada tahap akhir yaitu memeriksa jawaban kembali, siswa mampu menjelaskan cara untuk memeriksa jawaban yang telah diperoleh.

Berdasarkan data yang diperoleh melalui tes tertulis dan hasil wawancara, siswa mampu memecahkan permasalahan. Hal ini terbukti dari tahap-tahap pemecahan masalah yang dilakukan siswa secara benar, siswa mampu memahami masalah dengan baik. Kemudian siswa mampu melakukan perencanaan pemecahan masalah serta mampu menyelesaikan pemecahan masalah secara tepat. Selanjutnya siswa mampu untuk memeriksa kembali jawaban yang diperoleh menggunakan unsur yang telah diketahui pada soal.

Kemampuan penalaran subjek 2 dalam menyelesaikan masalah matematika

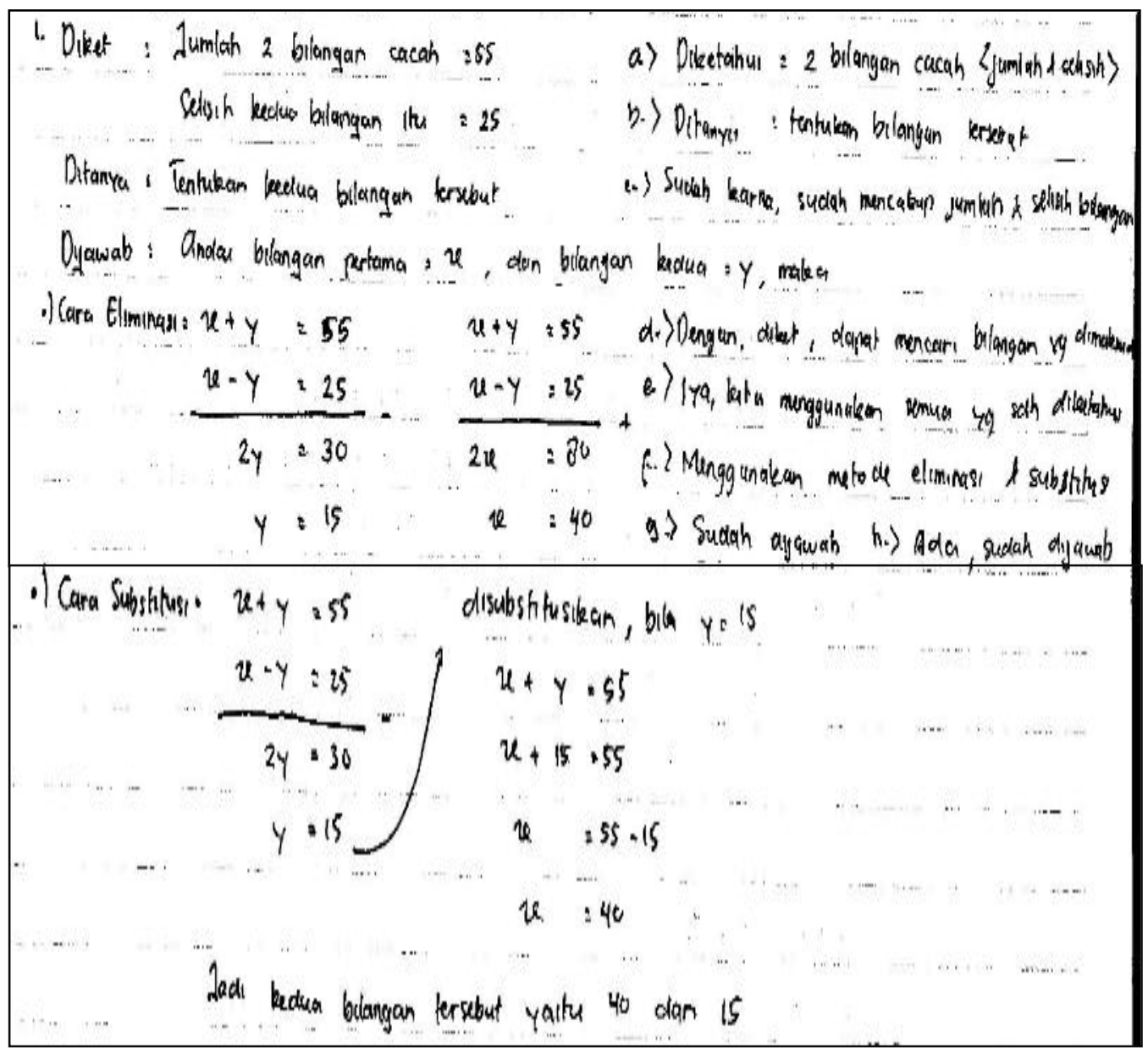

Gambar 2. Hasil Pekerjaan Subjek 2 dengan Kemampuan Penalaran Tinggi

Berdasarkan hasil pekerjaan siswa pada Gambar 2, terlihat bahwa siswa dapat memahami masalah. Hal ini dapat dilihat pada point $a$ dan $b$, siswa mampu 
menuliskan apa yang diketahui dari soal (syarat cukup) dan apa yang ditanyakan (syarat perlu). Setelah memahami masalah, maka langkah selanjutnya adalah merencanakan penyelesaian masalah. Perencanaan penyelesaian masalah dapat terlihat pada point $d, e, \operatorname{dan} f$. Pada point $d$, siswa tidak menjelaskan secara jelas hubungan antara yang diketahui dengan yang ditanyakan pada soal. Siswa hanya menuliskan bahwa "dengan diketahui, kita bisa mencari bilangan yang dimaksud". Langkah perencanaan selanjutnya adalah siswa menggunakan cara eliminasi dan subtitusi dengan menggunakan semua unsur yang diketahui pada soal untuk menjawab permasalahan yang ada. Pada awalnya siswa menuliskan pemisalan bilangan pertama adalah $x$ dan $y$ sebagai bilangan kedua.

Langkah selanjutnya adalah melaksanakan rencana penyelesaian masalah. penyelesaian masalah yang dikerjakan oleh siswa adalah menggunakan metode eliminasi dan subtitusi. Terlihat bahwa siswa menuliskan dua buah persamaan yaitu $x+y=55$ dan $x-y=25$. Pada cara eliminasi, awalnya siswa mengeliminasi variabel $x$ sehingga diperoleh nilai variabel $y=15$. Selanjutnya siswa melakukan eliminasi lagi pada variabel $y$ dan diperoleh nilai variabel $x=40$. Cara yang kedua yaitu dengan cara subsitusi. Pada cara subsitusi, memulai kembali dengan mengeliminasi variabel $x$ dan diperoleh nilai variabel $y=15$, kemudian siswa baru melakukan subtitusi nilai $y=15$ pada persamaan $x+y=55$ sehingga diperoleh variabel $x=40$. Tahap yang terakhir yaitu memeriksa kembali jawaban yang diperoleh. Pada tahap ini siswa tidak menuliskan bagaimana cara siswa memeriksa kembali jawaban yang telah diperoleh.

Berdasarkan data yang diperoleh melalui tes tertulis dan wawancara, diketahui bahwa siswa mampu memecahkan permasalahan pada soal. Hal ini terlihat dari tahap-tahap pemecahan yang dilakukan siswa secara benar. Siswa mampu memahami masalah dengan baik, kemudian siswa mampu melakukan perencanaan pemecahan masalah, serta mampu menyelesaikan pemecahan masalah secara tepat. Selanjutnya siswa mampu untuk memeriksa kembali jawaban yang diperoleh menggunakan unsur yang telah diketahui pada soal. 


\section{Kemampuan penalaran subjek 3 dalam menyelesaikan masalah matematika}

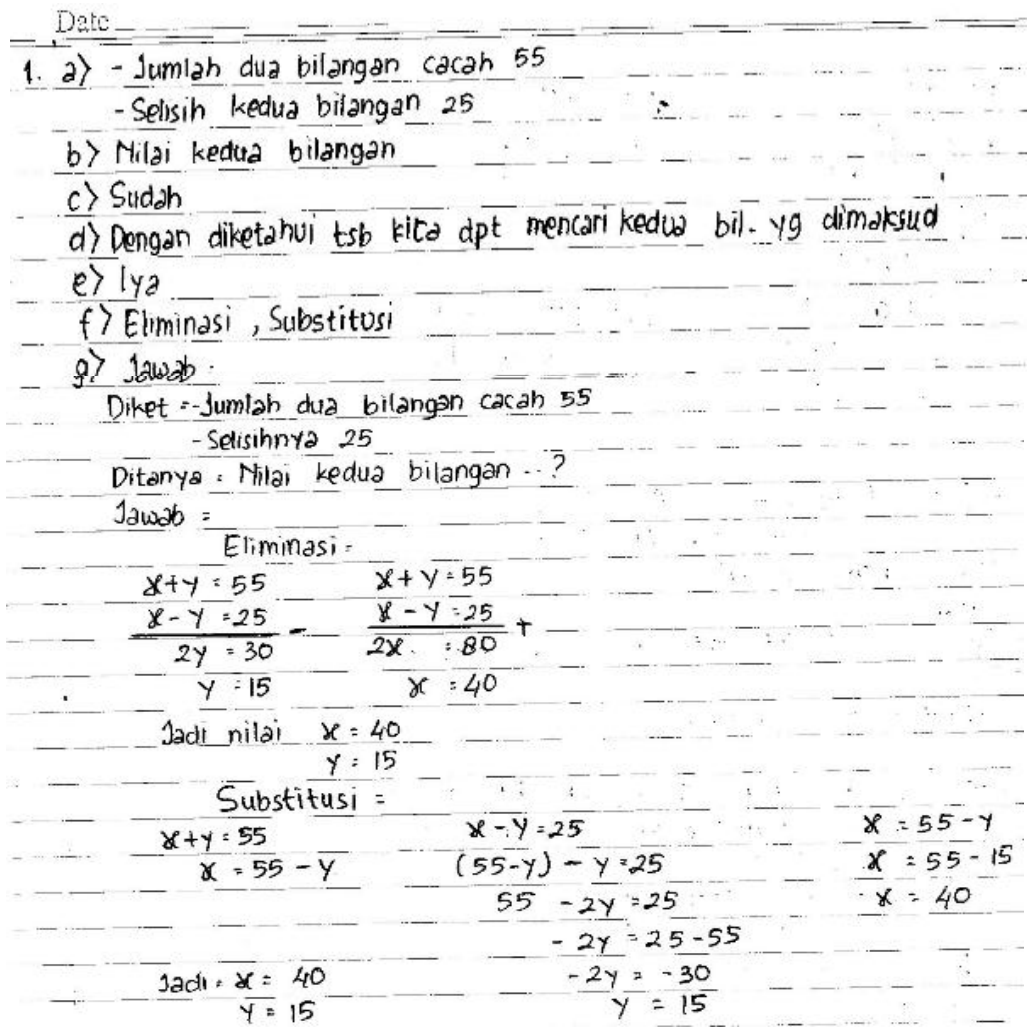

Gambar 3. Hasil pekerjaan subjek 3 dengan kemampuan penalaran sedang

Berdasarkan hasil pekerjaan siswa pada Gambar 3, dapat diketahui bahwa siswa dapat memahami masalah pada soal. Hal ini dapat dilihat pada point $a$ (syarat cukup) dan yang ditanyakan soal sebagai syarat perlu. Terlebih lagi siswa juga mampu menentukan kecukupan syarat pada soal sehingga mampu menjawab pertanyaan yang diberikan.

Setelah memahami masalah, maka langkah selanjutnya adalah merencanakan penyelesaian masalah. Pada perencanaan penyelesaian masalah dapat terlihat pada poin $d$, $e$, dan $f$. Pada poin $d$ siswa tidak menjelaskan secara jelas hubungan antara yang diketahui dengan yang ditanyakan pada soal. Langkah perencanaan selanjutnya siswa menggunakan cara eliminasi dan substitusi dengan menggunakan semua unsur yang diketahui pada soal untuk menjawab permasalahan yang ada.

Langkah selanjutnya adalah melaksanakan rencana penyelesaian masalah. Melaksanakan rencana pada prinsipnya adalah menyelesaikan masalah. Penyelesaian masalah yang dikerjakan oleh siswa menggunakan metode eliminasi 
dan substitusi. Terlihat bahwa siswa menuliskan dua buah persamaan yaitu $x+y=$ 55 dan $x-y=25$. Pada pekerjaan siswa tidak dijelaskan terlebih dahulu maksud dari dua persamaan tersebut dan apa arti variabel $x$ dan $y$. Pada cara eliminasi, awalnya siswa mengeliminasi variabel $x$ sehingga diperoleh nilai variabel $y=15$, kemudian siswa melakukan eliminasi lagi pada variabel $y$ dan diperoleh nilai variabel $x=40$. Cara yang kedua yaitu dengan cara subtitusi. Pada cara subtitusi, siswa memulai dengan persamaan $x+y=55$ dan dengan memindahkan variabel $y$ ke ruas kanan maka diperoleh $x=55-y$ dan diperoleh nilai variabel $y=15$. Kemudian siswa mensubtitusikan nilai $y=15$ ke $x=55-y$ dan diperoleh nilai $x=40$. Tahap yang terakhir yaitu memeriksa kembali jawaban yang diperoleh. Pada tahap ini siswa tidak menuliskan bagaimana cara siswa memeriksa kembali jawaban yang telah diperoleh.

Berdasarkan hasil wawancara, siswa mampu menjelaskan apa yang diketahui dan ditanyakan pada soal secara benar dan tepat. Selanjutnya dalam tahap penyelesaian masalah, siswa mampu menjelaskan secara tepat mengenai langkah penyelesaian yang dilakukan. Pada tahap akhir yaitu memeriksa jawaban kembali, siswa mampu menjelaskan cara untuk memeriksa jawaban yang diperoleh.

Berdasarkan data yang diperoleh memlalui tes tertulis dan hasil wawancara, siswa mampu memecahkan permasalahan. Hal ini terbukti dari tahaptahap pemecahan masalah yang dilakukan siswa secara benar. Siswa mampu memahami masalah dengan baik. Kemudian siswa mampu melakukan perencanaan pemecahan masalah serta mampu menyelesaikan pemecahan masalah secara tepat. Pada tahap memeriksa kembali, siswa mampu untuk memeriksa kembali jawaban yang diperoleh menggunakan informasi yang diketahui pada soal.

\section{Kemampuan penalaran subjek 4 dalam menyelesaikan masalah matematika}

Berdasarkan hasil pekerjaan siswa pada Gambar 4, terlihat bahwa siswa tidak mengerjakan soal yang diberikan berdasarkan langkah-langkah yang ada. Namun secara keseluruhan siswa dapat memahami permasalahan dengan baik. Siswa mampu menuliskan apa yang diketahui pada soal (syarat cukup) dan apa 
yang ditanyakan pada soal (sebagai syarat perlu). Siswa juga mampu menuliskan model matematika dengan benar dari apa yang diketahui dari soal.

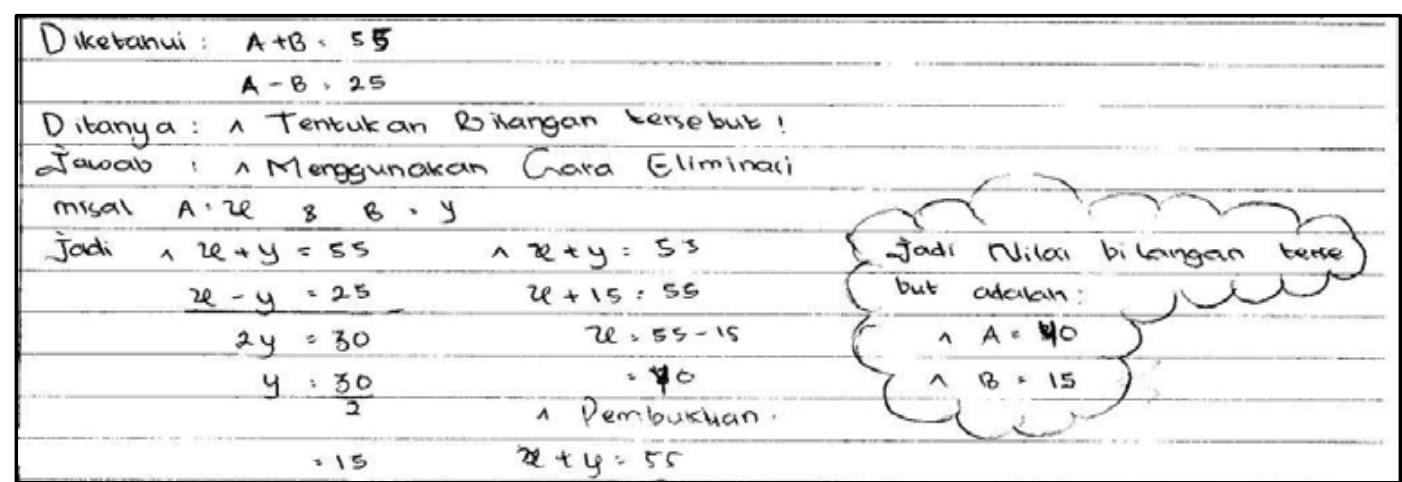

Gambar 4. Hasil Pekerjaan Subjek 4 dengan Kemampuan Penalaran Sedang

Setelah memahami masalah, maka langkah selanjutnya adalah merencanakan penyelesaian masalah. Pada perencanaan penyelesaian masalah dapat terlihat ketika siswa menulis pemisalan " $A=x$ " dan " $B=y$ ". Langkah selanjutnya adalah melaksanakan rencana penyelesaian masalah. Melaksanakan rencana pada prinsipnya adalah menyelesaiakan masalah. Penyelesaian masalah yang dikerjakan oleh siswa menggunakan metode eliminasi. Terlihat bahwa siswa menuliskan dua buah persamaan yaitu $x+y=55$ dan $x-y=25$. Pada cara eliminasi, awalnya siswa mengeliminasi variabel $x$ sehingga diperoleh nilai variabel $y=15$. Kemudian siswa melakukan eliminasi lagi pada variabel $y$ dan diperoleh nilai variabel $x=40$. Tahap yang terakhir yaitu memeriksa kembali jawaban yang diperoleh. Pada tahap ini siswa menuliskan bagaimana cara siswa memeriksa kembali jawaban yang telah diperoleh yaitu dengan menggunakan unsur yang diketahui pada soal.

Berdasarkan hasil wawancara dengan subjek 4, siswa tersebut mampu menjelaskan apa yang diketahui dan ditanyakan pada soal secara benar dan tepat. Siswa dapat menuliskan apa yang diketahui dan apa yang ditanyakan dalam bentuk rumus, simbol, atau kata-kata sederhana. Selanjutnya dalam tahap penyelesaian masalah siswa mampu menyelesaikan permasalahan menggunakan metode eliminasi. Siswa juga mampu menjelaskan bagaimana memeriksa kembali jawaban yang diperoleh.

Berdasarkan data yang diperoleh memalui tes tertulis dan hasil wawancara, siswa mampu memecahkan permasalahan. Hal ini terbukti dari tahap-tahap 
pemecahan masalah yang dilakukan siswa secara benar. Siswa mampu memahami masalah dengan baik. Siswa mampu menuliskan apa yang diketahui dan apa yang ditanyakan dalam bentuk rumus, simbol, atau kata-kata sederhana. Kemudian siswa mampu melakukan perencanaan pemecahan masalah serta mampu menyelesaikan pemecahan masalah secara tepat. Selanjutnya siswa mampu untuk memeriksa kembali jawaban yang diperoleh menggunakan unsur yang telah diketahui pada soal.

\section{Kemampuan penalaran subjek 5 dalam menyelesaikan masalah matematika}

$x=55$
$y=25$
$x+y=55+25=80$
$x-y=55-25=30$

Gambar 5. Hasil Pekerjaan Subjek 5 dengan Kemampuan Penalaran Rendah

Berdasarkan hasil pekerjaan siswa pada Gambar 5, terlihat bahwa siswa belum dapat menyelesaikan masalah berdasarkan perintah yang ada. Siswa tidak dapat menuliskan apa yang diketahui dan apa yang ditanyakan. Siswa langsung menuliskan tahap penyelesaian masalah. Namun, langkah penyelesaian masalah yang dilakukan siswa tidak tepat. Berdasarkan hasil wawancara dengan siswa, diketahui bahwa siswa tidak benar-benar memahami pertanyaan dan tidak mampu menyelesaikan masalah dengan sempurna. Siswa tidak menyelesaikan masalah dengan benar.

Menurut data yang diperoleh melalui tes tertulis dan hasil wawancara, siswa belum mampu memecahkan permasalahan pada soal. Hal ini nampak dari tahap-tahap pemecahan masalah yang dilakukan siswa adalah kurang tepat. Siswa belum mampu memahami masalah dengan baik. Siswa tidak melakukan perencanaan pemecahan masalah serta tidak mampu dalam menyelesaikan pemecahan masalah secara tepat.

Dari analisa hasil tes tertulis dan wawancara dengan kelima siswa diperoleh bahwa siswa dengan kemampuan penalaran tinggi dapat memahami masalah dengan baik. Pada langkah ini, kedua subjek (1 dan 2) memiliki kecenderungan tidak mengalami kesulitan dalam menentukan kecukupan syarat yang diperlukan untuk menyelesaikan permasalahan. Kedua subjek mampu 
menuliskan apa yang diketahui dari soal dengan bentuk model matematika. Dalam membuat rencana pemecahan masalah, subjek 1 dapat melakukan perencanaan penyelesaian masalah dengan baik. Subjek 1 dapat menjelaskan hubungan antara yang diketahui dengan yang ditanyakan pada soal secara tepat walaupun belum begitu rinci. Begitu juga pada subjek 2 yang juga mampu merencanakan penyelesaian masalah dengan baik. Kedua subjek menggunakan semua unsur yang diketahui untuk menyelesaikan masalah. Pada langkah melaksanakan rencana pemecahan masalah, kedua subjek mampu melaksanakannya dengan benar dan tepat. Pada tahap ini, siswa melaksanakan proses perhitungan sesuai dengan rencana yang telah disusunnya. Siswa mampu menerapkan metode eliminasi dan substitusi dalam menyelesaikan lima soal yang ada. Pada tahap memeriksa kembali jawaban, kedua subjek tidak menuliskannya pada lembar jawaban mereka. Akan tetapi kedua subjek mampu menjelaskan bagaimana cara mereka memeriksa kembali jawaban mereka ketika diwawancarai. Dengan demikian dapat disimpulkan bahwa kedua subjek mampu untuk memeriksa kembali jawaban mereka dengan menggunakan unsur-unsur yang diketahui pada soal.

Siswa dengan kemampuan penalaran sedang, dapat memahami masalah dengan baik. Subjek 3 mampu menentukan syarat cukup dan syarat perlu untuk dapat menyelesaikan pemecahan masalah. Demikian juga dengan subjek 4 yang mampu memahami masalah dengan baik. Pada langkah ini, kedua subjek memiliki kecenderungan tidak mengalami kesulitan dalam menentukan kecukupan syarat yang diperlukan untuk menyelesaikan permasalahan. Kedua subjek mampu menuliskan apa yang diketahui dari soal dengan bentuk model matematika. Dalam membuat rencana pemecahan masalah, subjek 3 dapat melakukan perencanaan penyelesaian masalah dengan baik. Subjek 3 dapat menjelaskan buhungan antara yang diketahui dengan uang ditanyakan pada soal secara tepat walaupun belum begitu rinci. Begitu juga pada subjek 4 yang mampu merencanakan penyelesaian masalah dengan baik. Kedua subjek menggunakan semua unsur yang diketahui untuk menyelesaikan masalah. Pada langkah melaksanakan rencana pemecahan masalah, kedua subjek mampu melaksanakannya dengan benar dan tepat. Pada tahap ini, siswa melaksanakan 
proses perhitungan sesuai dengan rencana yang telah disusunnya. Siswa mampu menerapkan metode eliminasi dan subtitusi dalam menyelesaikan soal yang ada. Pada tahap memeriksa kembali jawaban, kedua subjek tidak menuliskannya pada lembar jawaban mereka. Akan tetapi kedua subjek mampu menjelaskan bagaimana cara mereka memeriksa kembali jawaban mereka ketika diwawancarai. Dengan demikian, dapat disimpulkan bahwa kedua subjek mampu untuk memeriksa kembali jawaban mereka dengan menggunakan unsur-unsur yang diketahui pada soal.

Siswa dengan kemampuan penalaran rendah, yaitu subjek 5 belum dapat memahami masalah dengan baik. Siswa tidak mampu menentukan syarat cukup dan syarat perlu untuk dapat menyelesaikan pemecahan masalah. Pada langkah ini, subjek 5 memiliki kecenderungan mengalami kesulitan dalam menentukan kecukupan syarat yang diperlukan untuk menyelesaikan permasalahan. Subjek 5 belum mampu untuk menuliskan apa yang diketahui dari soal dengan bentuk model matematika. Dalam membuat rencana pemecahan masalah, subjek 5 tidak dapat melakukan perencanaan penyelesaian masalah dengan baik. Subjek 5 tidak dapat menjelaskan hubungan antara yang diketahui dengan yang ditanyakan pada soal secara tepat walaupun belum begitu rinci. Pada langkah melaksanakan rencana pemecahan masalah, subjek 5 tidak mampu melaksanakannya dengan benar dan tepat. Hal tersebut dikarenakan dari awal pemahaman masalah sampai pada perencanaan penyelesaikan masalah siswa tidak melaksanakannya dengan benar. Pada tahap memeriksa kembali jawaban, subjek 5 tidak mampu melaksanakan tahap ini dengan benar dan tepat. Siswa mengalami kesulitan dari awal pemecahan masalah sehingga pada tahap pemeriksaan kembali siswa tidak menuliskannya. Hasil ini juga didukung oleh penelitian-penelitian terdahulu yang dilakukan oleh Rosmiyadi, Sangila dkk, dan Irianti dkk tentang pemecahan masalah matematika (Rosmaiyadi, 2017) (Sangila, Safaria, Rahayu, \& Asran, 2019) (Irianti, Subanji, \& Chandra, 2016).

\section{SIMPULAN}

Siswa dengan kemampuan penalaran tinggi mampu memahami masalah dengan baik, mampu melakukan perencanaan pemecahan masalah, serta mampu 
menyelesaikan pemecahan masalah secara tepat. Selanjutnya siswa juga mampu untuk memeriksa kembali jawaban yang diperoleh menggunakan unsur yang telah diketahui pada soal.Siswa dengan kemampuan sedang mampu melakukan perencanaan pemecahan masalah serta mampu menyelesaikan pemecahan masalah secara tepat. Pada tahap memeriksa kembali, siswa mampu untuk memeriksa kembali jawaban yang diperoleh menggunakan informasi yang diketahui pada soal. Siswa dengan kemampuan penalaran rendah tidak mampu memahami dan merencanakan pemecahan masalah dengan baik. Mereka tidak mampu menyelesaikan dengan langkah-langkah yang benar dan tepat. Dalam memeriksa jawaban, mereka belum mampu untuk memeriksa kembali jawaban mereka dengan menggunakan unsur-unsur yang diketahui pada soal.

\section{DAFTAR PUSTAKA}

Brodie, K. (2010). Teaching mathematical reasoning in secondary school classrooms with contributions by. New York: Springer.

Inayah, N. (2016). Pengaruh kemampuan penalaran matematis dan gaya kognitif terhadap kemampuan komunikasi dan koneksi pada materi statistika siswa SMA. Journal of EST, 2(2), 74-80. https://doi.org/10.26858/est.v2i2.2105.

Irianti, N., Subanji, \& Chandra, T. (2016). Proses berpikir siswa quitter dalam menyelesaikan masalah SPLDV berdasarkan langkah-langkah Polya. JMPM: Jurnal Matematika dan Pendidikan Matematika, 1(2), 133-142. https://doi.org/10.26594/jmpm.v1i2.582.

Kamid. (2009). Identifikasi proses berpikir anak autis dalam menyelesaikan soal matematika. Seminar Nasional Matematika 2009, 907-920. Jember: Jurusan Matematika FMIPA Universitas Jember.

Mathematics, N. C. O. T. O. (2000). Principles and standards for school mathematics. United States of America: National Council of Teachers of Mathematics.

Polya, G. (1973). How to solve it-a new aspect of mathematical method (second edition). New Jersey: Princeton University Press.

Rosmaiyadi. (2017). Analisis kemampuan berpikir kritis matematis siswa dalam learning cycle 7E berdasarkan gaya belajar. AKSIOMA: Jurnal Program $\begin{array}{llll}\text { Studi Pendidikan } \quad \text { Matematika, } & \text { 6(1), }\end{array}$ http://dx.doi.org/10.24127/ajpm.v6i1.722.

Sangila, M. S., Safaria, S. A., Rahayu, L. R., \& Asran. (2019). Penalaran matematis antara siswa laki-laki dan perempuan yang bergaya kognitif impulsif dalam memecahkan masalah matematika. Al-TA'DIB, 12(1), 8398. https://doi.org/10.2307/2034794.

Wulandari, E. (2011). Meningkatkan kemampuan penalaran matematis siswa melalui pendekatan problem posing di kelas VIIIA SMP negeri 2 Yogyakarta. Yogyakarya: Universitas Negeri Yogyakarta.

Zaenab, S. (2015). Analisis kemampuan penalaran matematis siswa melalui 
Analisis Kemampuan Penalaran Siswa dalam Memecahkan Masalah Matematika Berdasarkan LangkahLangkah Polya

pendekatan problem posing di kelas X IPA 1 SMA negeri 9 Malang. JINoP (Jurnal Inovasi Pembelajaran), $1(1), \quad 90-97$. https://doi.org/10.22219/jinop.v1i1.2451 